\title{
Effect of Intravenous Glucose Infusion on Renal Function in Normal Man and in Insulin-Dependent Diabetics
}

\author{
J. Sandahl Christiansen, M. Frandsen and H.-H. Parving \\ Steno Memorial Hospital, Gentofte, and Department of Clinical Physiology and Medical Department C, Bispebjerg Hospital, \\ Copenhagen, Denmark
}

\begin{abstract}
Summary. The effect of intravenous glucose infusion on glomerular filtration rate and renal plasma flow (constant infusion technique using ${ }^{125}$ I-iothalamate and ${ }^{131}$ I-hippuran) and on urinary excretion of albumin and $\beta$-2-microglobulin were studied in ten normal subjects and seven metabolically well-controlled insulin-dependent diabetics. Following glucose infusion in normal subjects $(n=10)$ blood glucose increased from $4.7 \pm 0.1$ to $10.9 \pm 0.4 \mathrm{mmol} / 1(\mathrm{SEM})$ $(p \leqslant 0.01)$. Glomerular filtration rate increased from $116 \pm 2$ to $123 \pm 3 \mathrm{ml} / \mathrm{min} \times 1.73 \mathrm{~m}^{2}(p \leqslant 0.01)$, while no change in renal plasma flow was seen $552 \pm 11$ versus $553 \pm 18 \mathrm{ml} / \mathrm{min} \times 1.73 \mathrm{~m}^{2}$. Volume expansion with intravenous saline infusion in six of the normal subjects induced no changes in blood glucose or kidney function. In seven strictly controlled insulin-dependent diabetics, blood glucose values were raised from $4.6 \pm 0.4$ to $16.0 \pm 0.6 \mathrm{mmol} / 1$ and clamped by means of an 'artificial beta cell'. Glomerular filtration rate increased in all patients, from 133 \pm 5 to $140 \pm 6 \mathrm{ml} / \mathrm{min} \times 1.73 \mathrm{~m}^{2}(p \leqslant 0.02)$, as did renal plasma flow from $576 \pm 26$ to $623 \pm 38 \mathrm{ml} /$ $\min \times 1.73 \mathrm{~m}^{2}(p \leqslant 0.02)$. Urinary albumin excretion remained unchanged in both normal subjects and diabetics. $\beta$-2-microglobulin excretion rate increased significantly in the diabetics following glucose infusion, while no significant change was seen in the normal subjects. Our results show that hyperglycaemia per se contributes to the increased glomerular filtration rate and renal plasma flow in insulin-dependent diabetes.
\end{abstract}

Key words: Insulin-dependent diabetes, blood glucose concentration, glomerular filtration rate, renal plasma flow, albumin, $\beta$-2-microglobulin.
Glomerular filtration rate (GFR) is elevated in patients with Type 1 (insulin-dependent) diabetes mellitus, particularly during poor metabolic control [1-4]. Improvement of the metabolic control for one to two weeks induces a $10-20 \%$ reduction in GFR $[2,4,5]$, while kidney size remains unchanged [4]. Likewise, the enlarged glomerular filtration surface area demonstrated in newly diagnosed Type 1 diabetic patients is unaltered during the initial weeks of treatment [6]. Thus the rapidly reversible part of the GFR elevation in Type 1 diabetes seems independent of the demonstrated morphological changes in the kidneys. However, several other factors have been suggested to contribute to the elevation in kidney function e.g. growth hormone [2], hypoxia [3], glucagon [7] and hyperglycaemia [8]. Intravenous glucose infusion increases GFR (6-10\%) in normal man [8-10], while in diabetic patients GFR remains unchanged following oral glucose intake resulting in even higher plasma glucose concentrations [9]. Mogensen [9] suggested that plasma volume expansion and the concomitant reduction in plasma colloid osmotic pressure readily explained the rise in GFR following glucose infusion, while Brøchner-Mortensen [8] claimed that the elevated plasma glucose was the main factor involved.

The present study was designed to elucidate further the effect of moderate hyperglycaemia per se (i. e. blood glucose values within the range normally seen post-prandially in diabetic patients) on kidney function in normal man, and in metabolically well controlled diabetics.

\section{Subjects and Methods}

\section{Subjects}

Ten healthy male subjects with mean age 27 years (22-34 years) and mean body surface $1.96 \mathrm{~m}^{2}\left(1.80-2.27 \mathrm{~m}^{2}\right)$, and seven male Type 1 
Table 1. Clinical data in the seven insulin-dependent diabetics studied

\begin{tabular}{llllllr}
\hline Subject No. & $\begin{array}{l}\text { Age } \\
\text { (years) }\end{array}$ & $\begin{array}{l}\text { Duration of diabetes } \\
\text { (years) }\end{array}$ & $\begin{array}{l}\text { Body weight } \\
(\% \text { of ideal) }\end{array}$ & $\begin{array}{l}\text { Body surface area } \\
\left(\mathrm{m}^{2}\right)\end{array}$ & $\begin{array}{l}\text { Insulin requirement } \\
\left(\mathrm{IU} 24 \mathrm{~h}^{-1} \mathrm{~kg}^{-1}\right)\end{array}$ & $\begin{array}{l}\text { Blood glucose } \\
(\mathrm{mmol} / 1)\end{array}$ \\
\hline 1 & 20 & 3 & 82 & 1.84 & 0.80 & 7.0 \\
2 & 29 & 10 & 88 & 1.69 & 0.69 & 9.3 \\
3 & 28 & 1 & 91 & 1.64 & 1.00 & 7.2 \\
4 & 23 & 1 & 93 & 1.87 & 0.56 & 10.1 \\
5 & 21 & 4 & 92 & 1.83 & 0.97 & 8.1 \\
6 & 35 & 18 & 99 & 2.06 & 0.50 & 11.1 \\
7 & 37 & 2 & 105 & 1.75 & 0.41 & $9.3 \pm 0.7$ \\
\hline Mean \pm SEM & $.28 \pm 3$ & $6 \pm 2$ & $93 \pm 3$ & $1.81 \pm 0.05$ & $0.70 \pm 0.09$ & 9 \\
\hline
\end{tabular}

a Mean of post-prandial measurements in the morning at the last four visits to the out-patient clinic

diabetic patients were investigated after informed consent. Apart from insulin none of the subjects received any drugs. The clinical features of the patients studied are shown in Table 1.

The diabetics were selected from the out-patient clinic. Endogenous insulin secretion capacity was low when evaluated by the glucagon test [11]. Only patient No. 4 showed detectable amounts of C-peptide even after stimulation. The average post-prandial blood glucose at the previous four visits to the clinic was $9.3 \pm 0.7 \mathrm{mmol} / 1$ (SEM) (Table 1). Mean $24 \mathrm{~h}$ urinary glucose excretion on the same occasions was $23 \mathrm{~g} / 24 \mathrm{~h}$ (range $2-70 \mathrm{~g} / 24 \mathrm{~h}$ ).

All the diabetic subjects had normal retinae when examined by ophthalmoscopy through dilated pupils. None had clinical signs of nephropathy (proteinuria) or peripheral neuropathy.

\section{Kidney Function Measurements}

GFR and renal plasma flow (RPF) were measured by constant infusion techniques using ${ }^{125} \mathrm{I}$-iothalamate and ${ }^{131} \mathrm{I}$-hippuran respectively [12]. Measurements were started at $0800 \mathrm{~h}$ and performed in the fasting state. The subjects drank 1 litre of tap water at $0700 \mathrm{~h}$ and were given 0.25 litre every $20 \mathrm{~min}$ during the experiment. Measurements were performed in the supine position, the subjects standing only to void. Each clearance period lasted $20 \mathrm{~min}$. Thyroid uptake of iodide were blocked by potassium iodide $100 \mathrm{mg}$ for the two days before the experiment. Albumin and $\beta$-2-microglobulin in urine were measured by radioimmunoassay $[13,14]$. In the normal group the mean intra-individual coefficients of variation in the four consecutive control clearance periods were as follows: GFR $2.9 \%$, RPF $4.5 \%$, albumin excretion $11.0 \%$ and $\beta$-2-microglobulin excretion $20.3 \%$. The corresponding values in the diabetic group were: GFR $4.4 \%$, RPF $6.0 \%$, albumin excretion $18.6 \%$ and $\beta$-2-microglobulin excretion $17.0 \%$.

\section{Experimental Design}

Three types of experimental study were carried out:

A. Glucose infusion in normal subjects. Kidney function was studied before, during and after IV infusion of glucose $5 \mathrm{~g} / 100 \mathrm{ml}$ with added human albumin $15 \mathrm{~g} / 1$ (Albumin, Nordisk). The infusion rate was $600 \mathrm{ml} / \mathrm{h}$. Four clearance periods were carried out before, four periods during and four periods after the glucose infusion. Results from the transitional clearance periods No. 5 and 9 are omitted from calculations.

B. Saline infusion in normal subjects. Kidney function was studied in six of the subjects who had participated in series $A$. The procedure was exactly the same as described above, except that the glucose solution was replaced by saline $0.154 \mathrm{mmol} / 1$ with albumin $15 \mathrm{~g} / \mathrm{l}$.
C. Glucose infusion in Type 1 diabetic patients: Kidney function was measured before and during glucose infusion. The patients had their last SC injection of insulin in the morning and were admitted to the hospital in the afternoon of the day before the experiment. At $1500 \mathrm{~h}$ the patients were connected to an 'artificial beta cell' (Biostator) [15] for IV feed-back control of their blood glucose. The constants used for the algorithms [16] were: $\mathrm{KR}=70, \mathrm{KF}=67$, $\mathrm{QI}=40, \mathrm{BI}=70, \mathrm{RI}=12, \mathrm{FI} \simeq 400, \mathrm{BD}=50, \mathrm{RD}=25, \mathrm{QD}=20$ and $F D \simeq 200$. The run mode was $3: 0$. Patients were served their usual diet during the afternoon and evening, and were then kept fasting from midnight. Blood glucose levels were thus kept within the normal range for non-diabetics during the last $16 \mathrm{~h}$ before the kidney function measurement.

At $0730 \mathrm{~h}$ feed-back control was interrupted and the Biostator adjusted to infuse insulin at a constant rate (run mode $7: 1$ ). The infusion rate was chosen to equal the average infusion during the preceding $3 \mathrm{~h}$ (mean $21 \mathrm{mU} / \mathrm{min}$, range $18-25 \mathrm{mU} / \mathrm{min}$ ) and was continued unchanged for the rest of the experiment. Kidney function was measured in four clearance periods during normoglycaemia. Then blood glucose was elevated by an IV bolus injection of glucose $50 \mathrm{~g} / 100 \mathrm{ml}$, giving $2 \mathrm{ml} / \mathrm{kg}$ body weight, and the Biostator was adjusted to maintain blood glucose around $16 \mathrm{mmol} / \mathrm{l}$ by infusion of glucose $10 \mathrm{~g} / 100 \mathrm{ml}$ at a maximal infusion rate of $2 \mathrm{ml} /$ min; the mean infusion during the rest of the experiment was $1.2 \mathrm{ml} / \mathrm{min}$ (range $0.2-2.0 \mathrm{ml} / \mathrm{min}$ ). Kidney function measurements were then carried out for six further clearance periods. Results from the transitional clearance period No. 5 are omitted from calculations.

\section{Statistics}

The Wilcoxon matched-pairs test was used for comparison of mean values from clearance periods before and during infusions, omitting values from transitional periods. Values for GFR and RPF are corrected to $1.73 \mathrm{~m}^{2}$ body surface. Mean values are given with standard error of mean (SEM).

\section{Results}

Glucose infusion in normal subjects (study A) increased blood glucose from $4.7 \pm 0.1$ to $10.9 \pm$ $0.4 \mathrm{mmol} / 1$ during the infusion periods, with a decline to $3.6 \pm 0.2 \mathrm{mmol} / 1$ following infusion (Table 2). 

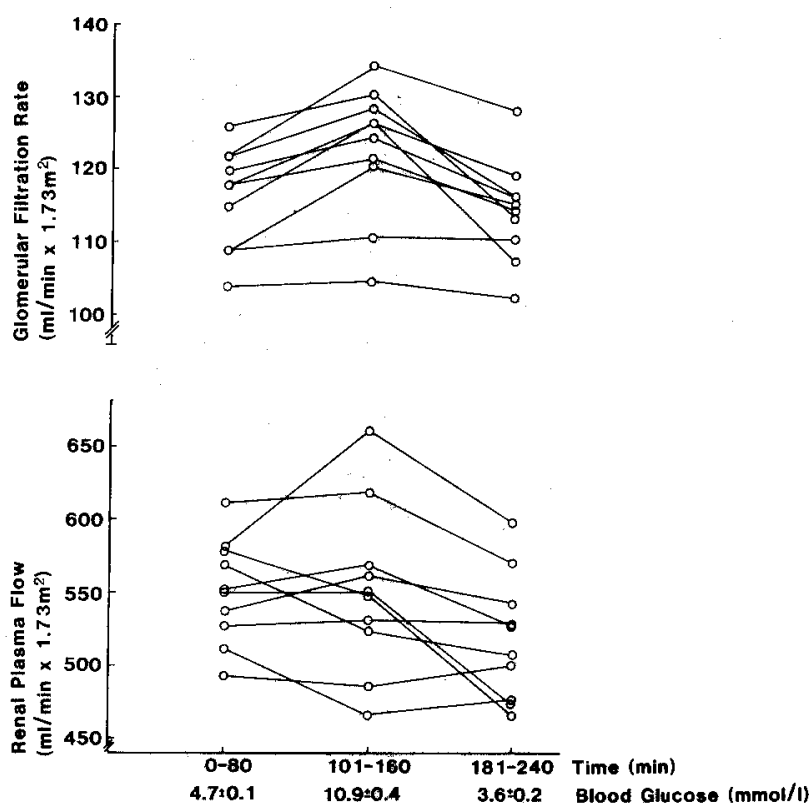

Fig. 1. Glomerular filtration rate and renal plasma flow in ten normal subjects before, during and after glucose infusion

GFR increased from $116 \pm 2$ to $123 \pm 3 \mathrm{ml} /$ $\min \times 1.73 \mathrm{~m}^{2}$ and returned to $115 \pm 2 \mathrm{ml} /$ $\min \times 1.73 \mathrm{~m}^{2}(p<0.01)$ (Table 2). The increase in GFR during glucose infusion was seen in all ten subjects (Fig. 1). No significant changes were seen in RPF (Table 2, Fig. 1).

Volume expansion with saline (study B) induced no changes in blood glucose, GFR or RPF (Table 2, Fig. 2). The changes in haematocrit and in plasma protein concentration were nearly identical in the two experimental studies A and B (Table 2). In neither of these studies in normal subjects were there any significant changes in urinary flow, albumin excretion or $\beta$-2-microglobulin excretion.

In well controlled diabetic patients (study C), blood glucose was raised from $4.6 \pm 0.4$ to $16.0 \pm$ $0.6 \mathrm{mmol} / \mathrm{l}$ (Table 3 ). GFR increased in all seven patients from $133 \pm 5 \mathrm{ml} / \mathrm{min} \times 1.73 \mathrm{~m}^{2}$ during normoglycaemia to $140 \pm 6 \mathrm{ml} / \mathrm{min} \times 1.73 \mathrm{~m}^{2}$ during hyperglycaemia $(p \leqslant 0.02)$. The corresponding values for RPF were $576 \pm 26$ and $623 \pm 38 \mathrm{ml} /$ $\min \times 1.73 \mathrm{~m}^{2}(p \leqslant 0.02)$. A significant positive correlation between $\triangle$ RPF and $\triangle$ GFR was found $(r=$ $0.89, p<0.01$ ) (Fig. 3). The decline in plasma protein concentration was of the same magnitude as that seen in experimental studies $\mathrm{A}$ and $\mathrm{B}$. Urinary flow increased from $14.0 \pm 1.1$ to $16.1 \pm 1.3 \mathrm{ml} / \mathrm{min}(p$ $\leqslant 0.02$ ).

Urinary albumin excretion rate in the control periods was elevated in the diabetics $(15 \pm 1 \mu \mathrm{g} / \mathrm{min})$ compared with the normal controls $(5.2 \pm 0.7 \mu \mathrm{g} /$
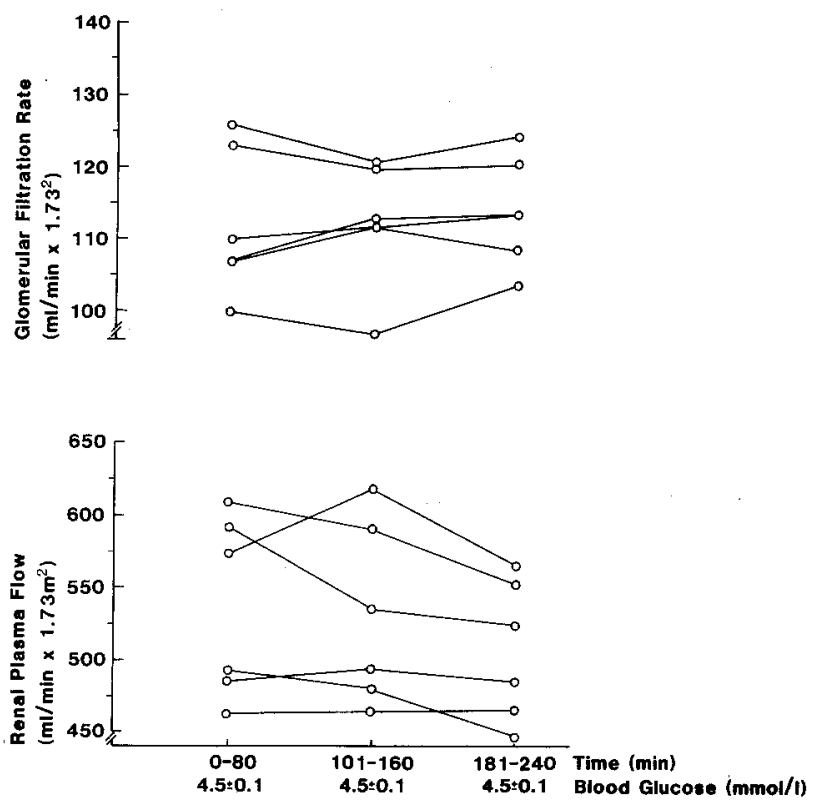

Fig. 2. Glomerular filtration rate and renal plasma flow in six normal subjects before, during and after saline infusion

$\min$ ), but showed no significant change following elevation of blood glucose (Table 3). $\beta$-2-microglobulin excretion rate was normal in the Type 1 diabetic patients during normoglycaemia, but showed a significant increase from $56 \pm 8$ to $83 \pm 10 \mathrm{ng} / \mathrm{min}$ during hyperglycaemia $(p \leqslant 0.02)$ (Table 3 ).

\section{Discussion}

The effect of plasma glucose elevation on kidney function in Type 1 (insulin-dependent) diabetics has been investigated only by Mogensen [9]. He studied seven male diabetic patients, with mean age 23 years and mean duration of diabetes 5 years, after an oral glucose load of $70 \mathrm{~g}$. GFR and RPF remained unchanged while plasma glucose increased from 7.2 to $16.1 \mathrm{mmol} / 1$. By contrast our study revealed an increase in GFR $(+6 \%)$ and RPF $(+11 \%)$ in all seven Type 1 diabetic patients. The clearance methods applied in the two studies were identical. The patients in both cases were males, comparable with respect to age and duration of diabetes. The decrease in plasma protein concentration was identical in the two studies. We selected patients in good metabolic control, and kept them normoglycaemic for the last $16 \mathrm{~h}$ before the clearance studies, by use of the Biostator. To avoid any influence of endogenous insulin secretion on GFR and RPF [17, 18], only patients with little or no C-peptide response to glucagon were included. Furthermore, only small changes in plasma insulin levels 
Table 2. Effect of glucose and saline infusion on kidney function in normal subjects

\begin{tabular}{|c|c|c|c|c|c|c|c|c|}
\hline & \multirow{2}{*}{$\begin{array}{l}\text { Clearance } \\
\text { period } \\
\text { (min) }\end{array}$} & \multirow{2}{*}{$\begin{array}{l}\text { Blood } \\
\text { glucose } \\
(\mathrm{mmol} / 1)\end{array}$} & \multirow{2}{*}{$\begin{array}{l}\text { Glomerular } \\
\text { filtration rate } \\
(\mathrm{ml} / \mathrm{min} \\
\left.\times 1.73 \mathrm{~m}^{2}\right)\end{array}$} & \multirow{2}{*}{$\begin{array}{l}\text { Renal plasma } \\
\text { flow } \\
(\mathrm{m} 1 / \mathrm{min} \\
\left.\times 1.73 \mathrm{~m}^{2}\right)\end{array}$} & \multirow{2}{*}{$\begin{array}{l}\text { Haematocrit } \\
(\mathrm{ml} / 100 \mathrm{ml})\end{array}$} & \multirow{2}{*}{$\begin{array}{l}\text { Plasma } \\
\text { protein } \\
(\mathrm{g} / 1)\end{array}$} & \multicolumn{2}{|c|}{ Urinary excretion of } \\
\hline & & & & & & & $\begin{array}{l}\text { albumin } \\
(\mu \mathrm{g} / \mathrm{min})\end{array}$ & $\begin{array}{l}\beta \text {-2-microglobulin } \\
(\mathrm{ng} / \mathrm{min})\end{array}$ \\
\hline \multirow{3}{*}{$\begin{array}{l}\text { Glucose } \\
\text { infusion } \\
(n=10)\end{array}$} & $\begin{array}{l}\text { Control } \\
(0-80)\end{array}$ & $4.7 \pm 0.1$ & $116 \pm 2^{a}$ & $552 \pm 11$ & $45 \pm 1$ & $69 \pm 1$ & $5.2 \pm 0.7$ & $58 \pm 15$ \\
\hline & $\begin{array}{l}\text { Glucose } \\
(101-160)\end{array}$ & $10.9 \pm 0.4$ & $123 \pm 3^{a}$ & $553 \pm 18$ & $43 \pm 1$ & $66 \pm 1$ & $5.0 \pm 0.4$ & $44 \pm 9$ \\
\hline & $\begin{array}{l}\text { Control } \\
(181-240)\end{array}$ & $3.6 \pm 0.2$ & $115 \pm 2$ & $520 \pm 14$ & $43 \pm 1$ & $68 \pm 1$ & $4.9 \pm 0.4$ & $44 \pm 9$ \\
\hline \multirow{3}{*}{$\begin{array}{l}\text { Saline } \\
\text { infusion } \\
(n=6)\end{array}$} & $\begin{array}{l}\text { Control } \\
(0-80)\end{array}$ & $4.5 \pm 0.1$ & $112 \pm 4$ & $537 \pm 26$ & $45 \pm 1$ & $70 \pm 1$ & $4.6 \pm 0.3$ & $46 \pm 16$ \\
\hline & $\begin{array}{l}\text { Saline } \\
(101-160)\end{array}$ & $4.5 \pm 0.1$ & $113 \pm 4$ & $531 \pm 26$ & $43 \pm 1$ & $66 \pm 1$ & $4.9 \pm 0.3$ & $38 \pm 13$ \\
\hline & $\begin{array}{l}\text { Control } \\
(181-240)\end{array}$ & $4.5 \pm 0.1$ & $115 \pm 3$ & $508 \pm 20$ & $43 \pm 1$ & $65 \pm 1$ & $4.7 \pm 0.3$ & $44 \pm 14$ \\
\hline
\end{tabular}

a $p<0.01$

Results are expressed as mean $\pm \mathrm{SEM}$

Table 3. Effect of glucose infusion on kidney function in seven insulin-dependent diabetics

\begin{tabular}{|c|c|c|c|c|c|c|c|}
\hline \multirow[t]{2}{*}{ Subject No. } & \multirow{2}{*}{$\begin{array}{l}\text { Clearance } \\
\text { period } \\
(\mathrm{min})\end{array}$} & \multirow{2}{*}{$\begin{array}{l}\text { Blood } \\
\text { glucose } \\
(\mathrm{mmol} / 1)\end{array}$} & \multirow{2}{*}{$\begin{array}{l}\text { Glomerular } \\
\text { filtration rate } \\
(\mathrm{ml} / \mathrm{min} \\
\left.\times 1.73 \mathrm{~m}^{2}\right)\end{array}$} & \multirow{2}{*}{$\begin{array}{l}\text { Renal plasma } \\
\text { flow } \\
(\mathrm{ml} / \mathrm{min} \\
\left.\times 1.73 \mathrm{~m}^{2}\right)\end{array}$} & \multirow{2}{*}{$\begin{array}{l}\text { Plasma protein } \\
(\mathrm{g} / \mathrm{l})\end{array}$} & \multicolumn{2}{|c|}{ Urinary excretion of } \\
\hline & & & & & & $\begin{array}{l}\text { albumin } \\
(\mu \mathrm{g} / \mathrm{min})\end{array}$ & $\begin{array}{l}\beta-2-\text { microglobulin } \\
\text { (ng/min) }\end{array}$ \\
\hline 1 & $\begin{array}{c}0-80 \\
101-200\end{array}$ & $\begin{array}{r}4.6 \pm 0.2 \\
17.1 \pm 1.1\end{array}$ & $\begin{array}{l}131 \pm 4 \\
133 \pm 3\end{array}$ & $\begin{array}{l}602 \pm 10 \\
646 \pm 23\end{array}$ & $\begin{array}{l}74 \pm 0 \\
71 \pm 1\end{array}$ & $\begin{array}{l}16 \pm 2 \\
21 \pm 3\end{array}$ & $\begin{array}{l}55 \pm 2 \\
78 \pm 3\end{array}$ \\
\hline 2 & $\begin{array}{c}0-80 \\
101-200\end{array}$ & $\begin{array}{r}5.1 \pm 0.0 \\
17.3 \pm 0.1\end{array}$ & $\begin{array}{l}136 \pm 2 \\
137 \pm 1\end{array}$ & $\begin{array}{l}548 \pm 12 \\
555 \pm 7\end{array}$ & $\begin{array}{l}65 \pm 0 \\
61 \pm 0\end{array}$ & $\begin{array}{l}12 \pm 1 \\
13 \pm 1\end{array}$ & $\begin{array}{l}33 \pm 2 \\
54 \pm 4\end{array}$ \\
\hline 3 & $\begin{array}{c}0-80 \\
101-200\end{array}$ & $\begin{array}{r}5.0 \pm 0.1 \\
16.7 \pm 0.2\end{array}$ & $\begin{array}{l}155 \pm 3 \\
171 \pm 1\end{array}$ & $\begin{array}{l}713 \pm 7 \\
841 \pm 6\end{array}$ & $\begin{array}{l}61 \pm 1 \\
60 \pm 1\end{array}$ & $\begin{array}{l}11 \pm 1 \\
13 \pm 1\end{array}$ & $\begin{array}{l}56 \pm 5 \\
91 \pm 6\end{array}$ \\
\hline 4 & $\begin{array}{c}0-80 \\
101-200\end{array}$ & $\begin{array}{r}3.5 \pm 0.0 \\
15.4 \pm 0.2\end{array}$ & $\begin{array}{l}119 \pm 3 \\
124 \pm 4\end{array}$ & $\begin{array}{l}569 \pm 17 \\
614 \pm 29\end{array}$ & $\begin{array}{l}65 \pm 1 \\
62 \pm 1\end{array}$ & $\begin{array}{l}13 \pm 2 \\
12 \pm 1\end{array}$ & $\begin{array}{l}71 \pm 4 \\
84 \pm 5\end{array}$ \\
\hline 5 & $\begin{array}{c}0-80 \\
101-200\end{array}$ & $\begin{array}{r}6.4 \pm 0.2 \\
15.8 \pm 0.2\end{array}$ & $\begin{array}{l}137 \pm 4 \\
140 \pm 3\end{array}$ & $\begin{array}{l}562 \pm 42 \\
593 \pm 23\end{array}$ & $\begin{array}{l}65 \pm 0 \\
63 \pm 0\end{array}$ & $\begin{array}{l}14 \pm 1 \\
11 \pm 1\end{array}$ & $\begin{array}{l}41 \pm 5 \\
68 \pm 3\end{array}$ \\
\hline 6 & $\begin{array}{c}0-80 \\
101-200\end{array}$ & $\begin{array}{r}3.7 \pm 0.1 \\
13.5 \pm 0.4\end{array}$ & $\begin{array}{l}139 \pm 5 \\
152 \pm 4\end{array}$ & $\begin{array}{l}496 \pm 26 \\
581 \pm 13\end{array}$ & $\begin{array}{l}73 \pm 1 \\
67 \pm 1\end{array}$ & $\begin{array}{l}15 \pm 2 \\
19 \pm 3\end{array}$ & $\begin{array}{c}95 \pm 9 \\
136 \pm 10\end{array}$ \\
\hline 7 & $\begin{array}{c}0-80 \\
101-200\end{array}$ & $\begin{array}{r}3.7 \pm 0.1 \\
16.0 \pm 0.5\end{array}$ & $\begin{array}{l}117 \pm 1 \\
123 \pm 2\end{array}$ & $\begin{array}{l}545 \pm 8 \\
557 \pm 7\end{array}$ & $\begin{array}{l}69 \pm 0 \\
63 \pm 0\end{array}$ & $\begin{array}{l}22 \pm 2 \\
15 \pm 1\end{array}$ & $\begin{array}{l}43 \pm 6 \\
73 \pm 5\end{array}$ \\
\hline Mean \pm SEM & $\begin{array}{c}1 \quad 0-80 \\
101-200\end{array}$ & $\begin{array}{r}4.6 \pm 0.4 \\
16.0 \pm 0.6\end{array}$ & $\begin{array}{l}133 \pm 5 \\
140 \pm 6 \\
p \leqslant 0.02\end{array}$ & $\begin{array}{l}576 \pm 26 \\
623 \pm 38 \\
p \leqslant 0.02\end{array}$ & $\begin{array}{l}67 \pm 2 \\
64 \pm 1 \\
p \leqslant 0.02\end{array}$ & $\begin{array}{l}15 \pm 1 \\
15 \pm 1\end{array}$ & $\begin{array}{c}56 \pm 8 \\
83 \pm 10 \\
p \leqslant 0.02\end{array}$ \\
\hline
\end{tabular}

Results are expressed as mean \pm SEM

occurred since the patients received insulin by infusion at a constant rate. The present control values for GFR and RPF were lower than those previously demonstrated by our laboratory in randomly chosen diabetic patients $[18,19]$. This agrees with our findings that strict metabolic control reduces GFR and RPF $[4$, 5]. We suggest that the effect of hyperglycaemia on GFR and RPF in diabetic patients depends on the metabolic state before and during the investigation. Furthermore, it is possible that the well known release of gastro-intestinal hormones induced by oral glucose may mask the effect of glucose per se.

Previous studies in normal man have demonstrated a $6-10 \%$ increase in GFR during IV glucose infusion resulting in a blood glucose increment $\geqslant 5 \mathrm{mmol} / 1[8-10]$. We demonstrated a $6 \%$ increase in GFR using the same approach as mentioned above. Mogensen [9] found no changes in GFR in man following an oral intake of $140 \mathrm{~g}$ glucose, sufficient only to raise plasma glucose from 4.4 to $7.6 \mathrm{mmol} / 1$. 


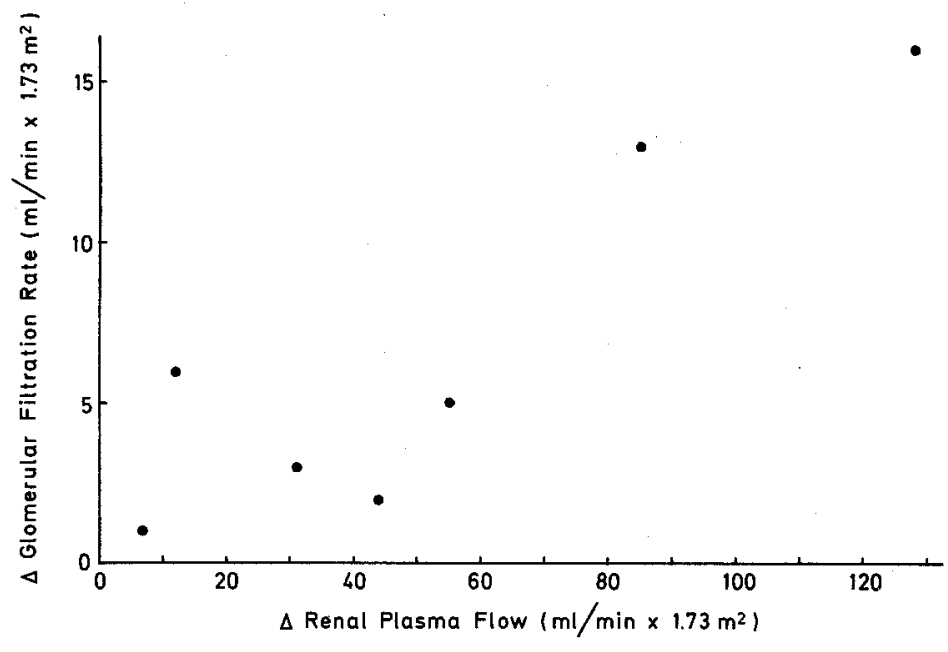

Fig. 3. Relationship between changes in renal plasma flow and glomerular filtration rate induced by glucose infusion in seven insulin-dependent diabetics $(r=0.89$, $p<0.01$ )
The enhancing effect of glucose infusion on GFR and RPF might be due to glucose per se or caused by some of the other variables, changed during the infusion. Mogensen [9] suggested that plasma volume expansion and reduction in colloid osmotic pressure could explain the observed increase in GFR during glucose infusion. In order to evaluate these possibilities, we induced volume expansion with saline (study B) in six of our normal subjects. The degree of plasma volume expansion (haematocrit) and of reduction in colloid osmotic pressure (plasma protein concentration) were identical in the saline infusion study $B$ and in the glucose infusion study A, both carried out on the same normal subjects. However, no changes in GFR or RPF took place during the saline infusion (Table 2). This is in agreement with the study of Baylis et al. [20] who in a rat model found that a decrease in plasma protein concentration did not reveal the expected enhancement in GFR - presumably because of a concomitant decline in the ultrafiltration coefficient, Kf. The possibility of a simple osmotic effect of glucose, has been investigated by Fox et al. [10] who, as mentioned above, found an increase in GFR during glucose infusion, but no change in GFR during infusion of equiosmolar amounts of xylose.

It is well documented that a close relationship exists between RPF and GFR, and that RPF is one of the major determinants of GFR, as reviewed by Brenner and Humes [21]. Our study also revealed a relationship between these two variables, however, only in the diabetic group (Fig. 3). Since errors in urine collection will affect RPF and GFR equally, there might be a tendency towards a false correlation in the present study. However, the influence of this error, is reduced by using the mean of several clearance periods. It should be mentioned that the RPF values found during glucose and saline infusion are minimum va- lues since the extraction fraction of hippuran tends to decrease during plasma volume expansion in normal man [22]. This is in agreement with the present finding of decreasing RPF values during saline infusion in the normal subjects (Table 2), and might explain that no increase in RPF could be found during glucose infusion in these subjects. Our results suggest that a rise in RPF is involved in the GFR elevation induced by hyperglycaemia, at least in insulin-dependent diabetic patients.

Urinary albumin excretion rate was found elevated during the control periods in the diabetics compared with the normal subjects. In similar patients elevated $[18,23,24]$ and normal $[7,25]$ levels of albumin excretion have been reported. Intravenous glucose infusion induced no changes in urinary excretion of albumin, neither in the normal subjects (Table 2), nor in the diabetics (Table 3). Recently, Hegedüs et al. [26] have demonstrated an increased urinary albumin excretion rate in normal man, but not in insulin-dependent diabetic patients, following an oral glucose intake of $1 \mathrm{~g} / \mathrm{kg}$ body weight. Since blood glucose and hence endogenous insulin secretion were more elevated in the normal subjects in our study, these variables cannot explain the observed differences between the two studies. Increased secretion of various gastrointestinal hormones occurring afteroral glucose intake may be involved. The increase in urinary volume observed in the former study might tend to elevate albumin excretion, although it cannot account for the difference.

The urinary excretion rates of $\beta$-2-microglobulin were not influenced by short-term hyperglycaemia in normal man (Table 2), while a significant increase was observed in the diabetics (Table 3 ). The difference in results between normal subjects and diabetics might be explained by the difference in blood glucose 
levels obtained during glucose infusion (11 versus $16 \mathrm{mmol} / \mathrm{l})$.

Our results show, that hyperglycaemia per se contributes to the increased GFR and RPF in insulin-dependent diabetes.

Acknowledgement. The secretarial assistance of Anita Jerichow is gratefully acknowledged. The study was supported by grants from the Danish Medical Research Council.

\section{References}

1. Stalder G, Schmid R, Wolff MV (1960) Funktionelle Mikroangiopathie der Nieren beim behandelten Diabetes Mellitus im Kindesalter. Dtsch Med Wochenschr 85:346-350

2. Mogensen CE (1972) Kidney function and glomerular permeability to macromolecules in juvenile diabetes. Dan Med Bull 19: (Suppl 3): 1-40

3. Ditzel J, Junker K (1972) Abnormal glomerular filtration rate, renal plasma flow, and renal protein excretion in recent and short-term diabetics. Br Med J II: 13-19

4. Christiansen JS, Gammelgaard J, Tronier B, Svendsen PAa, Parving H-H (1981) Kidney function and size in diabetics before and during initial insulin treatment. Kidney Int (in press)

5. Parving $\mathrm{H}-\mathrm{H}$, Rutili $\mathrm{F}$, Granath $\mathrm{K}$, Noer I, Deckert $T$, Lyngsøe J, Lassen NA (1979) Effect of metabolic regulation on renal leakiness to dextran molecules in short-term insulin-dependent diabetics. Diabetologia 17: 157-160

6. Kroustrup JP, Gundersen HJG, Østerby R (1977) Glomerular size and structure in diabetes mellitus III. Early enlargement of the capillary surface. Diabetologia 13:207-210

7. Parving H-H, Christiansen JS, Noer I, Tronier B, Mogensen CE (1980) The effect of glucagon infusion on kidney function in short-term insulin-dependent juvenile diabetes. Diabetologia 19:350-354

8. Brøchner-Mortensen J (1973) The glomerular filtration rate during moderate hyperglycaemia in normal man. Acta Med Scand 194:31-37

9. Mogensen CE (1971) Glomerular filtration rate and renal plasma flow in normal and diabetic man during elevation of blood sugar levels. Scand J Clin Lab Invest 28: 177-182

10. Fox M, Thier S, Rosenberg L, Segal S (1964) Impaired renal tubular function induced by sugar infusion in man. J Clin Endocrinol 24: 1318-1327

11. Faber OK, Binder C (1977) C-peptide response to glucagon. A test for the residual $\beta$-cell function in diabetes mellitus. Diabetes 26: 605-610

12. Mogensen CE (1971) Glomerular filtration rate and renal plasma flow in short-term and long-term juvenile diabetes mellitus. Scand J Clin Lab Invest 28:91-100
13. Miles DW, Mogensen CE, Gundersen HJG (1970) Radioimmunoassay for urinary albumin using a single antibody. Scand J Clin Lab Invest 26:5-11

14. Evrin PE, Peterson PA, Wide L, Berggård J (1971) Radioimmunoassay of $\beta$-2-microglobulin in human biological fluids. Scand J Clin Lab Invest 28: 439-444

15. Pfeiffer EF, Thum C, Clemens AH (1974) The artificial betacell. - A continuous control of blood sugar by external regulation of insulin infusion (Glucose controlled insulin infusionsystem). Horm Metab Res 487: 339-342

16. Clemens AH (1979) Control algorithms for artificial betacell. Horm Metab Res 8 (Suppl): 35-38

17. Mogensen CE, Christensen NJ, Gundersen HJG (1978) The acute effect of insulin on renal hemodynamics and protein excretion in diabetics. Diabetologia 15: 153-157

18. Christiansen JS, Frandsen M, Parving H-H (1981) The effect of intravenous insulin infusion on kidney function in insulin-dependent diabetes mellitus. Diabetologia 20: 199-204

19. Christiansen JS, Gammelgaard J, Frandsen M, Parving H-H (1981) Increased kidney size, glomerular filtration rate and renal plasma flow in short-term insulin-dependent diabetics. Diabetologia 20:451-456

20. Baylis C, Ichikawa I, Willis WT, Wilson CB, Brenner BM(1977) Dynamics of glomerular ultrafiltration. IX. Effects of plasma protein concentration. Am J Physiol 232: F58-F71

21. Brenner B, Humes HD (1977) Mechanisms of glomerular ultrafiltration. N Engl J Med 297: 148-154

22. Aurell M (1969) Renal response in man to plasma volume expansion and angiotensin. Scand J Clin Lab Invest 24: (Suppl. 112) 1-59

23. Viberti GC, Jarrett JR, McCartney M, Keen H (1978) Increased glomerular permeability to albumin induced by exercise in diabetic subjects. Diabetologia 14: 293-300

24. Baladimos MC, Chlouverakis C, Gleason RE, Jarrett RJ, Kahn CB, Keen H, Soeldner JS (1971) Urinary albumin excretion in the offspring of conjugal diabetics. Lancet $2: 295-300$

25. Mogensen CE (1971) Urinary albumin excretion in early and long-term juvenile diabetes. Scand J Clin Lab Invest 28: 183-193

26. Hegedüs L, Christensen NJ, Mogensen CE, Gundersen HJG (1980) Oral glucose increases urinary albumin excretion in normal subjects but not in insulin-dependent diabetics. Scand J Clin Lab Invest 40: 479-482

Received: 6 November 1980

and in revised form: 10 February 1981

Dr. J. Sandahl Christiansen

Steno Memorial Hospital

DK-2820 Gentofte, Denmark 